\title{
Barriers to SMEs Growth: An Exploratory Study of Khyber Pakhtunkhwa Manufacturing Sector
}

\author{
Fazal Haleem ${ }^{1}$, Muhammad Jehangir ${ }^{2}$, Zia Ullah ${ }^{3}$
}

\begin{abstract}
Small and Medium Enterprises (SMEs) play a pivotal role in an economy but in a developing country like Pakistan face various critical issues that hold back its potential contribution to the prosperity. An investigation is carried out to find out the issues faced by manufacturing SMEs in Khyber Pakhtunkhwa (KP), Pakistan. Using multi-case approach, data for the research has been gathered through sixty semi-structured interviews from the Chief Executive Officers (CEO) and Senior Managers. The general issues raised include extended and unscheduled power failure, poor support from government, stringent government regulations, higher business cost and narrow profit margin, corruption, political influence, and seasonal effects. The research serves a great deal of value for the investors, government, and chambers of commerce to take corrective action in time and to enhance the potential contribution of SMEs.
\end{abstract}

Key words: SME, issue, implication, growth, success, impediments, Pakistan.

\section{Introduction}

The economic and social contribution of SMEs cannot be overemphasized (Hussain, Ismail, \& Akhtar, 2015). It contributes to the prosperity of a country in terms of providing employment (Abor \& Quartey, 2010; J. Hussain et al., 2015), enhancing Gross Domestic Product (GDP)/ Gross National Product (GNP), giving birth to big and multinational corporations (Abor \& Quartey, 2010) as well as alleviating poverty (Ali, Humayun, \& Khan, 2014). Further, Hussain et al. (2015) report that SMEs paly its role in distribution of economic resources, growth of exports, and in the development of entrepreneurship. In addition, to some researchers (e.g. Khan \& Khalique, 2014; Ocloo, Akaba, \& Worwui-Brown, 2014), SMEs serves as a backbone to an economy and to others as a cushion to economic shocks (e.g. Hyder \& Lussier, 2016). Furthermore, these help in developing competitive advantages needed for sustainable economic development (Zulfiqar \& Batool, 2013). For these reasons, SMEs

1 PhD Scholar, Abdul Wali Khan University Mardan, KPK Pakistan. Email: haleemfazal@gmail.com

2 Assistant Professor, Abdul Wali Khan University Mardan, KPK Pakistan. Email: jehangir@awkum.edu.pk

3 Assistant Professor, Abdul Wali Khan University Mardan, KPK Pakistan. Email: zia_swat@yahoo.com

\begin{tabular}{ll} 
ARTICLE HISTORY & \\
19 Nov, 2018 Submission Received & 16 Feb, 2019 First Review \\
\hline 14 May, 2019 Second Review & 04 Sep, 2019 Third Review \\
\hline 06 Oct, 2019 Accepted &
\end{tabular}


are indispensible to economic stability (Hyder \& Lussier, 2016).

Even developed countries appreciate the contribution of SMEs in generating employment opportunities (Hyder \& Lussier, 2016). For instance, Hyder and Lussier (2016) reported the contribution of small firms in USA and Europe. In USA, small business consists of 99.7 percent of U.S. employer firms, including 48.5 percent in private sector employment, and a share of 33 percent in export. Similarly, in euro zone, small business made up more than 98 percent of all enterprises, contributing 67 percent in total employment, and 58 percent in gross value addition.

The importance of SMEs in the development of a country, especially a developing country, has been realized by governments (Hussain et al., 2015; Hyder \& Lussier, 2016). For instance, in developing countries such as Pakistan, SMEs make up more than 90 percent of all business with 40 percent contribution in GDP and 80 percent in employment of non-agriculture work force (“SMEDA," 2018)4.

The need for the research was felt due to number of reasons. For instance, Pakistan has set up an authority called small and medium enterprises development authority (SMEDA) that is responsible for developing and promoting SMEs sector by providing an enabling environment, business development services, and devising and implementing policies to address and resolve SMEs issues ("SMEDA," 2018). Similarly, the government of Khyber Pakhtunkhwa (KP) has established Khyber Pakhtunkhwa Economic Zones Development and Management Company (KPEZDMC) to sustain, develop, and promote rapid industrialization in KP by focusing on managing and organizing the existing and prospective modern industrial estates ("KPEZDMC," 2018). Moreover, commercial banks and specialized microfinance banks facilitate the existence and growth of SMEs by extending loan facilities. Besides these, the government has initiated a program called Prime Minister's Youth Business Loan Scheme for promoting entrepreneurship by lending to young business aspirants with an allocated fund of 3.7 billion rupees (Hyder \& Lussier, 2016).

Despite these efforts, Pakistan's position dropped from 144/190 to 147/190 in doing business which reflects the extent of ease/difficulty faced by local entrepreneurs in opening and running an SME when fulfilling the relevant regulatory requirements ("World Bank," 2017, "World Bank," 2018). Owing to the recent war and terror impact on businesses, Khyber Pakhtunkhwa (KP) had not been lucrative habitat for SMEs as this led to migration of SMEs to other provinces. Moreover, the growth and prosperity of SMEs operating in KP has been inferior to that of other provinces such as Punjab and Sindh (Sherazi, Iqbal, Asif, Rehman, \& Shah, 2013).

$4 \mathrm{http}: / /$ www.smeda.org/index.php?option=com_contentËview=article $B i d=7:$ state-of-smes-in-pakistan $\mathbb{E}$ catid $=15$ 
These reasons call for a research to explore the current impediments faced by SMEs and its immediate resolution.

SMEs have never been given it due importance and have been constantly ignored (e.g. Hyder \& Lussier, 2016; Khalique, Hasan, Md, Jamal, \& Sharri, 2011; Raziq, 2011) whilst big businesses have been favored by government (Hyder \& Lussier, 2016). This has led to the health of SMEs to an alarming stage (Khalique et al., 2011). Moreover, small business have high rate of failure globally (Hyder \& Lussier, 2016). All these points indicate that the barriers of SMEs need to addressed and resolved to benefit from its contribution in terms of high employment, alleviation of poverty, social unity and development, and contribution to economy etc. Further, a number of stakeholders such as current and prospective entrepreneurs, consulting firms, investors and lenders, and regulatory and related autonomous bodies would benefit from the research outcome by knowing the current issues, implications, and their resolution.

In order to identify the barriers faced by the SMEs, firstly chief executive and senior managers were asked to rate the barriers according to the degree of its adverse impact on their business. Secondly, they were requested to come up with suggestions on how to overcome the raised barriers. These barriers were broadly classified as internal, external, and government factors.

Internal factors consisted of lack of formal education, business on credit (no or little cash), no formal agreement with employees, short lease agreements, low working capital, use of technology, corruption at firm level, and low demand/low customer base. On the other hand, the external factor solicited questions as follows: seasonal effects, international influence, corruption at industry level, difficulty in competing foreign advanced countries, poor demand for products, higher business cost and narrow profit margin, monopoly of middlemen, political influence, non-availability of easy credit, and extended as well as unscheduled power failures. Last but not the least, the government factors consisted of questions: lack of government interest, poor forecasting, favorable attitude of government towards export quality products, government mismanagement and poor follow up, low remittances from abroad, government expenditure on construction work, poor support/subsidy from government, and stringent government regulations.

The next section reviews literature on SMEs issues and problems followed research methods, analysis, recommendations, and conclusion.

\section{Literature Review}

The review of literature reveals a plethora of research conducted on exploring factors responsible for affecting the growth and success of small and medium enterprises. 
Nevertheless, no consensus can be reached on a particular set of factors associated with the growth and success of SMEs from either the theoretical or empirical studies (Bouazza, Ardjouman, \& Abada, 2015). But, no doubt, SMEs face a number of challenges, impediments and bottlenecks that hinder its due contribution. In this regard, a number of researchers have identified factors that impede the growth of SMEs in developing countries (e.g. Abor \& Quartey, 2010; Bouazza et al., 2015; Chimucheka \& Mandipaka, 2015; Dar, Ahmed, \& Raziq, 2017; Harash, Al-Tamimi, \& Al-Timimi, 2014; Hyder \& Lussier, 2016; Jehangir, Haleem, Jan, \& Haq, 2016; Ocloo et al., 2014; Sherazi, Iqbal, Asif, Rehman, \& Shah, 2013). For instance, Sherazi et al. (2013) identified six major obstacles that hindered the growth of SMEs in Pakistan. These obstacles were financial constraints, surge in corruption, lack of social and technological support, inadequate training, and poor management and infrastructure in order of importance. Moreover, Dar et al. (2017) noted that SMEs in Pakistan faced issues related to financial, human, physical, and technological challenges.

Apart from Pakistan, researchers have come up with similar impediments faced by SMEs in other developing countries. For instance, Chimucheka and Mandipaka (2015) investigated challenges faced by SMEs in South Africa with respect to their set up, survival, and growth. They identified paucity of networking opportunities, constraints related to accessing finance, and poor support from government. Similarly, Bouazza et al. (2015) conducted research on factors responsible for affecting the growth of SMEs in Algeria. They noted a number of internal and external factors contributing to the poor performance of SMEs growth. The external factors were identified as rigid legal and regulatory framework, and difficulty in accessing external financial and human resources. On the other hand, characteristics of entrepreneurs and management capacity in terms of marketing skills and technological capacities were identified as part of internal factors responsible for the poor growth of SMEs.

Ocloo et al. (2014) conducted a survey on 320 SMEs in Ghana to find out the challenges faced by SMEs with respect to globalization and competitiveness. They noted increased competition as the highest ranked challenge followed by advances in technology, inadequate infrastructure, poor knowledge about the market, and rigid government policies and regulations. Similarly, Harash et al. (2014) investigated the relationship between government policy and financial performance of SMEs in Iraq. They reported positive and significant impact of government policy on SMEs competitiveness and profitability. Moreover, they noted stringent laws, regulations, and rules as impediment in the way of SMEs sector development. Moreover, Abor and Quartey (2010) identified a number of impediments that hindered the development of SMEs in Ghana namely financial constraints, paucity of training and development, poor institutional capacity, inadequate existence of rules, regulations, and laws, and 
obsolete technology.

Besides these factors, some researchers unearthed the reasons for the success or failure of SMEs such as Hyder and Lussier (2016) and Jehangir et al. (2016). Jehangir et al. (2016) found that the top three critical success factors (CSF) for SMEs were the attitude, knowledge and effective communication of the managers respectively. On the other hand, the top three critical failure factors (CFF) were found to be the shrinking financial resources, inability to adapt to changing environment and shrinking market respectively. Moreover, the government support as CSF proved to be the least affecting one. Likewise, the least CFF's have been reported as poor financial management and poor marketing. On the other hand, Hyder and Lussier (2016) found that if small businesses had adequate capital, maintain good record keeping and financial control, had industry and management experience, had specific plans, use of professional advice, had more education, had an easier time staffing, had better product stage and economic timing, and had marketing skills they would increase their chances of success. On the contrary, the failed firms exhibited these four issues namely the need for capital, the need for business plans, the need for proper staffing, and the need for partners.

To overcome some of these issues that impede the development of SMEs, Ali et al. (2014) suggested the development of formal financial markets with simple lending procedures, easy and inexpensive credits, and laws enforcing credit rights. Similarly, M. Hussain, Ajmal, Khan, and Saber (2015) recommended the development of business incubation centers to sustain and enhance the growth of SMEs. These incubators help improve entrepreneurship and enhance technological innovations in the SMEs sector.

The review of literature suggests that there are number of factors responsible for the impeded growth of SMEs existing in the literature under the names of barriers, impediments and challenges. These barriers, impediments, and challenges can be broadly grouped as internal, external, and government related factors.

\section{Research Methodology}

The section covers aspects of sample frame, sample size, sources of data, and data analysis techniques.

\subsection{Sampling frame and size}

The sampling frame of the study consists of all the SMEs manufacturing operating in KP province of Pakistan. SMEs manufacturing firms operating in KP province of Pakistan has been the population of the research. KP as population has been selected due to ease of availability of data in terms of time, finance and collection of data. The 
sample size was sixty firms as data were collected from sixty firms selected randomly.

\subsection{Sources of data}

Hyder and Lussier (2016) reported that there exists no formal database of small business in Pakistan. Therefore, following Hyder and Lussier (2016), we collected data with help of the local chambers of commerce and trade associations. In addition, majority of SMEs are owned and managed by persons who are not highly educated indicating the difficulty of obtaining data. For these reasons, only primary data was collected through sixty semi-structured interviews from chief executives and managers of different manufacturing firms across KP. These interviews were conducted face to face, mostly, at the sites of the manufacturing firms during the 2018. The semi structured interview questionnaire has been developed by the researcher and it is based on review of literature.

Interviewees were asked to rate the barriers according to the degree of adverse impact these have on their business. These barriers were broadly classified as internal, external, and government factors. Secondly, they were requested to come up with suggestions on how to overcome the raised barriers. The semi-structured interview questionnaire may please be found in appendix.

\subsection{Tools for analysis}

In line with the research objectives and data collected, qualitative data analysis techniques, thematic analysis, were applied for analysis of data. The responses from the interviewees were recorded first. Using MS Excel, these records were then used to identify the patterns, similarities, and dissimilarities among the barriers. The criticality of the barrier was determined by the frequency of the issue raised by the interviewees. Finally, the main barriers and suggestions for overcoming these were summarized and reported.

\section{Analysis}

Sixty semi-structured interviews from different firms across KP were conducted and their respective findings as per sector are summarized and briefed. Table no. 4.1 depicts the data taken in terms of interviews from different manufacturing sectors. As found out that different manufacturing sectors face some general and some specific issues, therefore, both are addressed under their respective titles.

\subsection{General barriers}


Table: 4.1 Demographics of Respondents

\begin{tabular}{|c|c|c|c|c|c|}
\hline S\# & Demographic & CEO & Senior Officer & Total & Grand \\
\hline 1 & Designation & 25 & 35 & 60 & 60 \\
\hline \multirow[t]{4}{*}{2} & Experience & & & & \\
\hline & more than 12 Years & 6 & 8 & 14 & \\
\hline & more than 8 Years & 12 & 14 & 26 & \\
\hline & more than 5 Years & 5 & 15 & 20 & 60 \\
\hline \multirow[t]{5}{*}{3} & Education & & & & \\
\hline & Post Graduate & 3 & 4 & 7 & \\
\hline & Under Graduate & 16 & 14 & 30 & \\
\hline & Secondary & 10 & 8 & 18 & \\
\hline & Primary or no & 5 & 0 & 5 & 60 \\
\hline \multirow[t]{7}{*}{4} & Industry & & & & \\
\hline & Food & 2 & 5 & 7 & \\
\hline & Marble & 6 & 11 & 17 & \\
\hline & Pharmaceutical & 2 & 8 & 10 & \\
\hline & Plastic & 3 & 5 & 8 & \\
\hline & RCC/ Concrete & 4 & 7 & 11 & \\
\hline & Textile & 3 & 4 & 7 & 60 \\
\hline \multirow[t]{7}{*}{5} & Location & & & & \\
\hline & Peshawar & 5 & 8 & 13 & \\
\hline & Haripur & 2 & 3 & 5 & \\
\hline & Swat & 6 & 8 & 14 & \\
\hline & Buner & 4 & 9 & 13 & \\
\hline & Mardan & 2 & 4 & 6 & \\
\hline & Nowshehra & 3 & 6 & 9 & 60 \\
\hline
\end{tabular}

Source: Based on authors' own research

General barriers raised by the SMEs manufacturing firms include extended and unscheduled power failure, poor support from government, stringent government regulations, higher business cost and narrow profit margin, corruption, political influence, and seasonal effects. Each of these issues is briefly explained below.

\subsubsection{Extended power failure}


100 percent of interviewees attributed the main reasons for the losses of factories to the frequent extended and unscheduled power failure. They opined that the extended and unscheduled power failure not only increases the cost of production but adversely impact employer-employee relationship. Moreover, the extended and unscheduled power failure discourages employers/owners to keep employees on monthly salary. By the same token, employees who work on contract basis suffers as well as they cannot make enough money. This makes the sector unattractive for employees and they start looking for work somewhere else. This point has also been raised by Hyder and Lussier (2016) that shortage of electricity has been one of the main issues faced by SMEs. More to the point, Pakistan stands 147/190 in doing business which reflects the ease/difficulty with respect to complying with the regulatory requirements in attaining these facilities. Despite the existence of SMEDA and KPEZDMC the issue still prevails across the country.

\subsubsection{Poor support from government}

According to $35 \%$ of the interviewees, businesses are migrating to other countries which are business conducive/support e.g. Sri Lanka and Bangladesh. They further explained the reasons behind migrating business abroad including unsatisfactory performance of relevant authorities, poor infrastructure, no/poor subsidy, lack of government interest, poor forecasting, and security problems. The lack of support from government was reported by ul Haq (2007) as well. He claimed that the government itself was the cause of impediment to innovation. Similarly, Hyder and Lussier (2016) noted that cost of doing business in Pakistan is high that suggest that local governments should make their laws simple and easy to comply with. Moreover, they noted that Pakistani government supports the big business and do not give due attention to the SMEs.

4.1.2.1 Unsatisfactory performance of Khyber Pakhtunkhwa Economic Zone Development and Management Company (KPEZDMC)

25 percent respondents opined that KPEZDMC fails to provide even the basic facilities on the ground such as drainage, drinking water, and metaled roads. Hyder and Lussier (2016) suggested that regulatory authorities (e.g. SMEDA and KPEZD$\mathrm{MC}$ ) need to be provided with more financial and human resources to cater to the needs of SMEs.

\subsubsection{Poor infrastructure}

In view of 35 percent interviewees, even the industrial estate conditions are miserable Moreover, there is either no or very poor railway system in the country for cheap, reliable, and quick delivery of goods. Similarly, the roads are very narrow and 
rough largely. All this not only wastes the precious time of business but increases the cost of doing business in terms of higher rent as well.

\subsubsection{Withdrawn/less subsidy}

45 percent respondents perceive government as not very much supportive in helping out the business. With the exemption of a few business sectors that receive subsidy, others have not been subsidized. Those who received subsidy in past are facing reduction in their subsidies such as flour mills.

\subsubsection{Lack of government interest}

Respondents, relating to food manufacturing, showed dissatisfaction with respect to government interest in boosting the SMEs. According to the $30 \%$ interviewees, fruit pulp worth billions is wasted every year as there are no machinery and food processing factories to take advantage of it. Similarly, government takes no serious action to make use of these and to export the same and contribute to the balance of trade. This point has also been noted by Hyder and Lussier (2016) that Pakistani government favors big business more than SMEs.

\subsubsection{Poor forecasting}

40 percent the respondents perceive government to fails to forecast the needs and demand of the products. Likewise, it fails to advise SMEs on what to produce, how much to produce, and where to produce. This way not only farmers suffer but also production turns into waste especially the food industry. Therefore, they demanded that government needs to set up food processing units, cold storages, preservative centers, and need to educate farmers. Again the strengthening of the relevant authorities (SMEDA and KPEZDMC) in terms of finances and human resources would resolve these issues as suggested by Hyder and Lussier (2016).

\subsubsection{Security problems}

According to $65 \%$ respondents, Taliban (militants) and other militants groups have been big threat to the continuous operations of the business particularly in different parts of $\mathrm{KP}$, especially agencies, because raw materials are acquired from these agencies. Hyder and Lussier (2016) reported that security, electricity, and political instability were the three main issues that businesses encountered in Pakistan.

\subsubsection{Stringent regulations}

According to 70 percent interviewees, the businesses are highly regulated and 
are required to comply with so many regulations, have to maintain huge paper work, and to keep inform the different government offices, for instance, Employee Old-age Benefit Institution (EOBI), Tax department, Khyber Pakhtunkhwa Economic Zone Development and Management Company (KPEZDMC), Sarhad Development Authority (SDA), etc., which are based often away from each other thus causing problems for business to focus on its core operations rather fulfilling the requirements and shuttling to different offices placed in different offices. This problem is also eminent from the world bank report on doing business that reports Pakistan position at 147/190 that represents the extent of ease/difficulty with respect to complying with the regulatory requirements ("World Bank," 2018). Similarly, researchers (e.g. Bouazza et al., 2015; Hyder \& Lussier, 2016; Saleem, Kaleem, Malik, \& Raza, 2011) pointed out the restrictive local laws that impede the growth and success of SMEs.

In case of marble industry, the government regulations regarding imposing taxes and controlling the sale of explosives have furthered the pressure on raw materials suppliers. The unstable and expensive raw materials make it difficult for the businesses to offer the same quality products in the market for the same price whilst facing cut throat competition.

Moreover, KP government has much regularized the flour mill industry by buying the wheat from them on fixed price and the flour owners are not allowed to buy wheat from else where they want. Sometimes the district administration imposes restrictions on selling flour and related products in other districts. This makes the production and selling of flour and other by-products difficult/non-profitable.

\subsubsection{High business cost and narrow profit margin}

As per 75 percent respondents, the Pakistani economy is not fully documented and a great deal of trust deficit exists in business dealings, therefore, most of business persons prefer cash. The tax on cash withdrawals from banks is very high that not only makes the business deals expensive but sometimes discourages business person to undertake further initiatives/deals. The World Bank report reinforces the fact that the business environment in Pakistan is not conducive and enabling as reflected by its position of 147/190 in doing business ("World Bank," 2018).

In case of Marble industry, the business cost is rising faster in terms of higher royalties (from Rs.30 to Rs.60 per ton), expensive power/electricity, transportation cost, etc. Whilst the sale price is hardly inflated that makes the profit margin very thin and makes it difficult/undesirable for some business to operate for high investment and low return.

Silk industry faces the availability of skilled labor which is not only scarce but 
expensive. The reason is that silk industry especially in Swat regressed dramatically as the technical/skill worker either went in search of new jobs to some other places or started working in other sectors to earn their bread. This finding reinforces the results of Syed, Ahmadani, Shaikh, and Shaikh (2012) that skill labor is one of the biggest challenges that SMEs face. Moreover, the extended power failure discourages owners to keep the labor on wages/salary. Similarly, the skilled labor are not ready to work on contract basis as they cannot make enough money due to power failure, therefore, either demand salary or higher contract money. Similarly, raw materials are expensive because they are either imported or procured at higher price.

Overall, the business cost has grown in terms of expensive energy (e.g. electricity, gas) and high taxes with respect to international standards particularly UAE, Sri Lanka and Bangladesh. As a result investors consider conducting their businesses abroad. This is even evident from Pakistan position of 147/190 in doing business ("World Bank," 2018).

\subsubsection{Corruption}

40 percent Interviewees perceive Pakistan business environment as highly exposed to corruption as the government regulators/watch dogs/ monitors expect bribery in return for giving green signal/ approval etc. The profitability is also adversely affected by the expected amount of money (bribery which was named as entertainment) as the government officials' demand more entertainment than amount of money put aside. This issue of corruption reinforces the finding of Sherazi et al. (2013) who reported that it is one of the main obstacles that impede the growth of SMEs in Pakistan.

\subsubsection{Political influence}

In view of 55 percent respondents, in the regime of Pakistan People Party, Gadoon Amazai Industrial Estate was set up to boost the business there and to curb the drug smuggling as this used to be a center. However, the successor government of Muslim League discontinued the policy and pulled the plug on the funds and other incentives and subsidies that were previously provided. By the same token, the interviewees appreciated the initiative taken by the current KP government to setting up KP Economic Zone Business Development and Management Company (no such initiative had been taken by other provinces) but worried at the same time about the future continuity of the company by successive governments. This attitude of government (political instability) has significantly affected the investors' confidence in investing in Pakistan. Hyder and Lussier (2016) reported that political instability has been one of the major impediments that the businesses face in Pakistan. Therefore, investment in Pakistan is low (indigenous and foreign) and local business persons tend to migrate 
to other business conducive/ supportive environment such as Bangladesh, Sri Lanka and UAE among others.

\subsection{Specific barriers}

The specific barriers faced by different manufacturing sectors with its implications are discussed briefly.

\subsubsection{Marble industry}

The main issues raised by the executives included lack of formal education, business on credit, high business cost and narrow profit margin, lack of formal agreement with employees, extended power failure, security problems, and strict government regulations.

\subsubsection{Lack of formal education}

According to the 40 percent interviews, lack of formal education is the biggest contributing factor in the failure of factories. As these owners do not have the skills to assess their business in terms of where are they heading? Are they making any money or incurring losses? Similarly, majority of firms do not prepare their financial statements and after couple of years they either close down or sell the business off to someone else. Researchers (e.g. Bouazza et al., 2015; Hyder \& Lussier, 2016; King \& McGrath, 2002) emphasized that entrepreneurs/managers of SMEs needs to be qualified and trained to increase the chances of success.

\subsubsection{Business on credit}

65 percent respondents perceive that the success factor in the marble industry in the area is that if you pay in cash as you go you get the best quality of stone, raw material, which is prerequisite for your efficient and quality product output. If the stone is of lower quality you incur production cost, transportation, taxes, commissions, etc. and then the lower quality and low production do not meet your company expenses and therefore incur losses. Hyder and Lussier (2016) highlighted the importance of making the loan facility easy and simple.

\subsubsection{Lack of formal agreements with employees}

According to 35 percent interviewees, employees usually quit the job without furnishing any proper notice. This puts the ongoing business in trouble by becoming short of the needed labor. Moreover, it takes time to hunt the required number of employees and to train and develop them. The issue is serious in nature as the business has to abide by its contracts with customers and suppliers and failure of which 
mars the worth business trust. To cope with this issue a mechanism needs to be set up to take care of employees and employers as well. The employees usually leave the job as they cannot make substantial living in the factory for long and extended power failures. Further, they do not have any social benefits/security. This issue has also been identified by J. Hussain et al. (2015) that lack of enforcement of employees' rights and contracts that could benefit both the employees and employers. The relevant authorities (e.g. SMEDA and KPEZDMC) should devise and implement policies to overcome this issue.

\subsubsection{Roller-Compacted Concrete (RCC) manufacturing factories}

According to interviewees, short lease agreements, low working capital, low demand/customer base, and government regulations are comprised of the main issues faced by SMEs.

\subsubsection{Short lease agreements}

As per 80 percent respondents, usually the lease agreements of business sites are from 2 to 5 years and customers are often given guarantees of 50 years. Upon completion of lease agreements, majority of the investors leave premises either on purpose or by obligation. Similarly, the business on lease try to make as much money as possible often by comprising on many quality related aspects.

\subsubsection{Low working capital}

45 percent interviewees stated that sometimes their businesses need fund to meet the working capital. For this, often they are forced to sell the products on low prices that further exacerbate their profit margin. In addition, these businesses are expected to pay wages to labors and pay other operating expenses. Moreover, the suppliers do not supply the raw materials on time that put the firm further in trouble. This leads to quitting of labors that adds more to the pressure/troubles of business. Similarly, the businesses have high fixed cost to meet as well therefore, they need to keep producing and selling. SMEDA should play its role in ensuring the simple and easy availability of credit facilities.

\subsubsection{Low demand/customer base}

According to the 60 percent respondents, the concrete/RCC products are often used by poor people who cannot afford modern style of building. So with the return of Afghan refugees, who were the main customers of the product, the demand for the products has declined. In addition, the poor customers demand products with the lowest prices as possible that either leads to compromise on quality or low sales. 


\subsubsection{Juice manufacturing firms}

75 percent respondents agreed on the set of problems faced by juice manufacturing firms: lack of government interest, poor forecasting, government mismanagement and poor follow up.

\subsubsection{Lack of government interest}

70 percent interviewees complained that fruit pulp worth billions is wasted every year as there is no machinery and food processing factories to take advantage of it. In addition, government takes no serious action to make use of these and to export the same and earn some foreign exchange. Government should strengthen the existing authorities and establish further specialized economic zones to overcome these shortcomings.

\subsubsection{Poor forecasting}

As per 60 percent respondents, government also fails to forecast the needs and demands of the products as well as what to produce, how much to produce, and where to produce. This way not only farmers suffer but also production turns into waste especially the food industry. The government needs to set up food processing units and preservative centers and also educate farmers on how to do preservations etc. Government should strengthen the existing authorities and establish further specialized economic zones to overcome these shortcomings.

\subsubsection{Government mismanagement and poor follow up}

30 percent interviewees admitted that sometimes government and other non-governmental organization (NGO) take action to take care of these issues but these are mostly confined to the paper work. Some others fail due to the fact that stakeholders are not taken into confidence and the right persons to take decisions are often missing. Similarly, some stakeholders, especially the farmers, do not take the matters seriously and therefore either do not participate or stick to the policy for longer for reasons such as other farmers do not stick to the government precautions and instructions to do or not to do something. As suggested by Hyder and Lussier (2016), government should run campaign to aware the masses of the importance of issue and do proper follow up to make sure the implementation of policies.

\subsubsection{Crush plants}

65 percent interviewees attributed the main reasons for the low sale/downfall of crush plants relate to the overall local economy which is related to the remittances from abroad especially United Arab Emirates (UAE) and meager spending of local 
government in developmental projects.

\subsubsection{Low remittance from abroad (UAE etc.)}

According to 40 percent interviewees, majority of both skilled and non-skilled work force of the KP especially Malakand division is employed in Saudi Arabia and Middle East. Crisis in these countries has adversely affected the remittances. The people do not have money to do construction work, therefore, demand for the crush and other construction materials have dropped significantly.

\subsubsection{Government expenditure on construction work}

Similarly local government is not keen on carrying out developmental projects. Consequently, the demand for the products has dropped significantly.

\subsubsection{Flour mills}

80 percent interviewees perceived that the sector mainly encounters these bottlenecks that include withdrawn/less subsidy, poor demand for the product, and more stringent regulations.

\subsubsection{Poor demand}

Flour mills are not producing much because their production has been suffered due to several reasons such as no/less export/smuggling to Afghanistan and exodus flow of Afghanis back to their country. Moreover, the flour mills do not produce their normal product lines and by-products as produced by other flour mills in Punjab and other parts of the country due to old technology/machinery and low demand.

\subsubsection{Stringent regulations}

Moreover, KP government has much regularized the flour mill industry by buying the wheat from them on fixed prices and they are not allowed to buy wheat from where they want. Sometimes the district administration imposes restriction on selling the products in other districts. This makes the production and selling of flour and other by-products not feasible. As per Hyder and Lussier (2016) suggestions, government should ease the restrictive local bylaws to facilitate the businesses.

\subsubsection{Plastic industries}

As per 85 percent interviewees, the challenges that hold back plastic industries include no support from government, poor infrastructure, no satisfactory performance of Khyber Pakhtunkhwa Economic Zone Development and Management Company (KPEZDMC), and high business cost. 


\subsubsection{Plastics (polythene bags)}

Plastic industry especially polythene bags suffers from several problems such as seasonal effects, international influences, political influence, corruption, high customer awareness, and high raw material cost.

\subsubsection{Seasonal effects}

The performance of the business is affected significantly by the seasonal effects (Apr to Oct).

\subsubsection{International influences}

Polythene is a by-product of petroleum which is imported particularly from Saudi Arabia, Oman, Iran, and USA. Due to the fluctuation in the prices of petroleum, the business cost (freight, salary, energy, raw material) is highly volatile. This affects their profitability and provision of stable quality at the stable prices. In this regard, government should either subsidize or offer some sort of insurance to these firms to curb with price volatility.

\subsubsection{High customer awareness}

Customers are incredibly well informed/ aware of the quality, prices and the processes. Therefore, they negotiate the prices and leave the business with narrow profit margin.

\subsubsection{Paints}

In the paints sector, 80 percent interviewees highlighted these barriers: government favoring imported products, high taxes (even on withdrawal), stringent regulations, difficulty in competing foreign advanced countries, and tendency of business person towards businesses pose some challenges to the local paint sector.

\subsubsection{Favorable attitude of government towards imported products/export quality products}

The government tendency of issuing tenders in favor of foreign firms based in Pakistan with their huge contracts and not accepting the locally manufactured products certainly adversely impact the local manufacturers by not being able to sell their products in large scale thus badly impact their performance and further impairs their production and quality.

The Theory of Equifinality holds true that positive balance of trade can be achieved either by increasing the export or by lowering down the imports. Whereas government does not take serious action by discouraging imports and encouraging 
exports rather do the exact opposite by not buying the locally manufactured products and preferring the imported products. Moreover, higher taxes on import should be levied to discourage such purchases.

\subsubsection{Difficulty in competing foreign advanced countries}

Pakistan is not very much technologically advanced. Therefore, most Pakistani businesses import the technology, materials, and often the skilled/technical persons from advanced countries. In such case, how come can Pakistani businesses compete with technologically advanced countries as the advances in technology come very fast? Moreover, the government does not provide the needed resources/facilities to the business persons such as subsidies, uninterrupted supply of electrics, gas, water, easy loans, and business contusive infrastructure etc. This is also evident from Pakistan position of 147/190 in doing business ("World Bank," 2018).

\subsubsection{Tendency of business persons towards businesses}

Due to the aforementioned problems, particularly no support from government especially not favoring the locally manufacturing industry and not providing them with the necessary conducive environment, the business persons are more inclined towards investing in real estate and trading business. As the two are safe investments relatively and offers stable return with low risk and fewer headaches. On the other hand, the manufacturing business is highly risky as the business persons have to bear the fruits/ consequences of positive/negative market demand. In the words of a CEO, the trading business and manufacturing businesses are just like 'girlfriend' and 'wife' respectively.

\subsubsection{Silk industry}

According to the 85 percent respondents, the industry has been suffering from poor demand, use of old technology, higher labor cost, monopoly of middlemen, lack of government support, lack of access to easy an inexpensive credit, and power failure.

\subsubsection{Poor demand}

Silk mills suffer because demand for the product has dropped significantly especially because of the raw materials/finished products used to be exported/smuggled to the neighboring countries. Further, the local demand is not growing that much for one main reason that cheap cloth is imported from China and other countries.

\subsubsection{Use of old technology}

Most of silk mills have been using old and poor machinery due to which the 
productivity and cost of production arise. Poor demand and very narrow margin of profit does not encourage owners to upgrade their technologies.

\subsubsection{Monopoly of middlemen}

The raw cloth are bought by a very few agents and who sell the raw cloth in Punjab and other part of the country on their negotiated prices thus the manufacturers do not much benefit from their production rather the agents/middlemen take advantage of buying at low cost and selling it back at higher prices in the market.

\subsubsection{Lack of government support}

Though government has taken some initiatives of providing subsidy to some manufacturers to resume production but still the profit margin is very low. However, until fair price set up is assured by removing the monopoly of middlemen/ agents the manufacturer will keep suffering.

\subsubsection{Lack of access to easy and simple loans}

These silk mill owners need to be given loans to enhance their machinery and production methods. Most of the time manufacturers have to sell their products to the agents on a very low price as they encounter problems with the storage, paying wages, and other operating and fixed expenses.

\subsubsection{Power failures}

Especially power (electricity) and its unscheduled and unstable supply of power further exacerbate the industry conditions by not being able to produce enough. Second, the skilled labors working on salary become burden on the company as the company does not produce enough and pay salaries to the employees and other fixed cost. In case of being on contract basis, skilled labors suffer by not making enough money. This situation leads the skilled labor to quit their jobs and seek jobs somewhere else.

\section{Recommendations}

These recommendations are based on the valuable input of CEOs and senior managers to overcome some of issues SMEs have been facing:

I. Facilities Provision: Some CEOs suggested that government should take serious action in facilitating the business community by providing necessary testing laboratories for quality checks, food processing and reservation facilities, cold storage etc. to improve productivity, diminish loses, and earn foreign exchanges.

II. Regulatory Framework: Relevant authorities should simplify the regulatory pro- 
cedures by introducing one window operation (SDA, Tax, EOBI etc.) and save the business community from the trouble of going and maintaining different records for different government departments.

III. Legislative Framework: Government and relevant authorizes should make it mandatory, or at least give some quota, on government organization to purchase only locally manufactured products to boost and improve the country's entrepreneurial confidence and productivity.

IV. Power failure: Government needs to make sure availability of stable and sufficient supply of power to all industrial zones and other manufacturing concentrated places across the country.

V. Easy Credit: Government needs to strengthen the existing authorities with more financial and human resources to help the troubling SMEs to overcome their financial problems. Government can play its role by making the procedure simple, easy, and cheap. It should also help entrepreneurs in making them aware of these facilities.

VI. Business Incubation Center: Government should also pay attention to setting up business incubation centers across the country to develop and sustain the growth of SMEs by promoting entrepreneurship, innovation and technologies.

VII.Government Reforms: Government should bring reforms in banking system with respect to interest rates, collateral requirements, and loan application procedures. In addition, SMEs should be given a range of financial facilities such as financial and operating leases. Similar reforms in tax system to increase the tax base and not to overburden the SMEs.

VIII. Focus on Research and Development, and Training and Development: More resources should be dedicated to research and development and training and development both at individual, SMEs, level and on the relevant authorities' level to increase the chances of success and improve productivity. In this regard, government can play its role in bringing awareness and giving training opportunities to SMEs managers and CEOs by cooperating with local chambers of commerce.

IX. Awareness: Government should play its role in bringing awareness of the reward of self-employment among the would-be entrepreneurs. It should also encourage women to participate in entrepreneurial activities as they make large portion of Pakistani population.

X. Universities: Universities, particularly business schools, should play its role by equipping the business graduates with the skills, knowledge, and experience to 
start their own businesses upon graduation. This could be done by establishing good relationship with industries, giving out internship opportunities in the industries, setting up own business incubation centers, and promoting entrepreneurial societies etc.

\section{Conclusions}

The study investigated barriers that impeded the growth of manufacturing SMEs operating in Khyber Pakhtunkhwa (KP), Pakistan. The study concludes that though government has taken some initiatives to facilitate SMEs in Pakistan but there still exist plethora of problems that impede the growth and success of SMEs. The prevailing pressing issues in general include extended and unscheduled power failure, poor support from government, stringent government regulations, higher business cost and narrow profit margin, corruption, political influence, and seasonal effects.

The understanding and addressal of these issues is of vital importance to a number of stakeholders such as the current and prospective owners/managers of SMEs, regulators and policy makers, lending institutions, investors, and business consultants. Current and would-be CEOs and business managers would benefit from comprehending the current business environment with respect to the issues faced by SMEs by making better plans and policies to increase their chances of success. Similarly, this could help regulators and policy makers in developing effective legal and regulatory frameworks and policies to provide a business conducive-environment. By the same token, lending institutions and investors could get a better idea where to extend loans and invest and how much. This would not only help them find the right market for their product/money but would generate and offer right products accordingly. All these would help improve the health of SMEs and thus help benefiting from its contribution to economy, employment creation, poverty alleviation, and increase in exports and foreign exchange.

For future research work, the perception of CEOs and Senior Managers could be tested for congruence among their views and its ultimate impact on firm performance. Similar research could be carried out in a particular industry to find out industry specific barriers faced by SMEs.

\section{References}

Abor, J., \& Quartey, P. (2010). Issues in SME Development in Ghana and South Africa. International Research Journal of Finance and Economics, 39(39), 218-228. Retrieved from http://www.eurojournals. com/irjfe_39_15.pdf

Ali, S., Humayun, R., \& Khan, M. A. (2014). The role of small and medium enterprises and poverty 
in Pakistan: An empirical analysis. Theoretical and Applied Economics, 18(4 (593)), 67-80. JOUR, Asociatia Generala a Economistilor din Romania-AGER.

Bouazza, A. B., Ardjouman, D., \& Abada, O. (2015). Establishing the factors affecting the growth of small and medium-sized enterprises in Algeria. American International journal of Social science, 4(2), 101-115. JOUR.

Chimucheka, T., \& Mandipaka, F. (2015). Challenges faced by small, medium and micro enterprises in the Nkonkobe Municipality. The International Business $\mathcal{E}$ Economics Research Journal (Online), 14(2), 309. JOUR, The Clute Institute.

Dar, M. S., Ahmed, S., \& Raziq, A. (2017). Small and medium-size enterprises in Pakistan: Definition and critical issues. Pakistan Business Review, 19(1), 46-70.

ul Haq, N. (2007). Entrepreneurship in Pakistan. (DE Working Paper No. 29). Islamabad.

Harash, E., Al-Tamimi, K., \& Al-Timimi, S. (2014). The relationship between government policy and financial performance: A study on the SMEs in Iraq. China-USA Business Review, 13(4), 290-295.

Hussain, J., Ismail, K., \& Akhtar, C. S. (2015). Market orientation and organizational performance: case of Pakistani SMEs. Arabian Journal of Business and Management Review, 5(5), 1-6.

Hussain, M., Ajmal, M. M., Khan, M., \& Saber, H. (2015). Competitive priorities and knowledge management: An empirical investigation of manufacturing companies in UAE. Journal of Manufacturing Technology Management, 26(6), 791-806.

Hyder, S., \& Lussier, R. N. (2016). Why businesses succeed or fail: A study on small businesses in Pakistan. Journal of Entrepreneurship in Emerging Economies, 8(1), 82-100.

Jehangir, M., Haleem, F., Jan, S., \& Haq, Z. U. (2016). Why do some businesses succeed whilst others fail? Evidence from District Swat, KPK. Journal of Applied Environmental and Biological Sciences, 6(2), 153-163.

Khalique, M., Hasan, A., Md, I., Jamal, A., \& Sharri, N. (2011). Challenges for Pakistani SMEs in a knowledge-based economy. Indus Journal of Management $\mathcal{B}$ Social Sciences, 5(2), 74-80.

Khan, M. W. J., \& Khalique, M. (2014). A holistic review of empirical studies of strategic planning and future research avenues. International Journal of Academic Research in Economics and Management Sciences, 3(6), 53-72. Retrieved from http://hrmars.com/index.php/journals/papers/IJAREMS/ v3-i6/1291

King, K., \& McGrath, S. (2002). Globalization, enterprise and knowledge: Educational training and development. International Review of Education, 50(1).

KPEZDMC. (2018). About us. Retrieved on August 25, 2018, from http://kpezdmc.org.pk/about

Ocloo, C. E., Akaba, S., \& Worwui-Brown, D. K. (2014). Globalization and competitiveness: Challenges of small and medium enterprises (SMEs) in Accra, Ghana. International Journal of Business and Social 
Science, 5(4), 287-296.

Raziq, A. (2011). High performance management practices in manufacturing and service-based SMEs. A comparative study. Proceedings of the 24th Annual Conference of the Small Enterprise Association of Australia and New Zealand (SEAANZ 2011) (pp. 114-137).

Saleem, S., Kaleem, M. M., Malik, N., \& Raza, M. (2011). An examination of challenges and prospects of microfinance sector of Pakistan. European Journal of Economics, Finance and Administrative Sciences, $31,146-159$.

Sherazi, S. K., Iqbal, M. Z., Asif, M., Rehman, K., \& Shah, S. S. H. (2013). Obstacles to small and medium enterprises in Pakistan. Principal component analysis approach. Middle-East journal of scientific research, 13(10), 1325-1334.

Syed, A., Ahmadani, M. M., Shaikh, N., \& Shaikh, F. M. (2012). Impact analysis of SMEs sector in economic development of Pakistan: A case of Sindh. Journal of Asian Business Strategy, 2(2), 44-53.

World Bank. (2017). Doing business 2017. Retrieved on August 25, 2018, from http://www.doingbusiness. org/reports/ /media/WBG/DoingBusiness/Documents/Profiles/Regional/DB2017/SA.pdf

World Bank. (2018). Doing business 2018. Retrieved on August 25, 2018, from http://www.doingbusiness. org/ $\sim /$ media/WBG/DoingBusiness/Documents/Profiles/Country/PAK.pdf

Zulfiqar, S., \& Batool, S. A. (2013). Analyzing the input output relationship of small and medium enterprises in Pakistan: An econometric approach. International Journal of Business and Economic Development, 1(1), 66-73. 


\section{Appendix \# 1}

\section{Semi-structured Interview Questionnaire}

Please rate the following issues according to the degree of its adverse impact on your business.

\begin{tabular}{|c|c|c|c|c|c|c|}
\hline Factor & Issue & \multicolumn{5}{|c|}{ Rating } \\
\hline \multirow{8}{*}{$\begin{array}{l}\text { Internal } \\
\text { Factors }\end{array}$} & - Lack of Formal Education & $0 \%$ & $25 \%$ & $50 \%$ & $75 \%$ & $100 \%$ \\
\hline & - Business on Credit (no or little cash) & $0 \%$ & $25 \%$ & $50 \%$ & $75 \%$ & $100 \%$ \\
\hline & - No Formal Agreement with employees & $0 \%$ & $25 \%$ & $50 \%$ & $75 \%$ & $100 \%$ \\
\hline & - Short lease agreements & $0 \%$ & $25 \%$ & $50 \%$ & $75 \%$ & $100 \%$ \\
\hline & - Low working capital & $0 \%$ & $25 \%$ & $50 \%$ & $75 \%$ & $100 \%$ \\
\hline & - Use of Old Technology & $0 \%$ & $25 \%$ & $50 \%$ & $75 \%$ & $100 \%$ \\
\hline & - Corruption at firm level & $0 \%$ & $25 \%$ & $50 \%$ & $75 \%$ & $100 \%$ \\
\hline & - Low demand/customer base & $0 \%$ & $25 \%$ & $50 \%$ & $75 \%$ & $100 \%$ \\
\hline \multirow{8}{*}{$\begin{array}{c}\text { Govern- } \\
\text { ment }\end{array}$} & - Lack of government interest & $0 \%$ & $25 \%$ & $50 \%$ & $75 \%$ & $100 \%$ \\
\hline & - Poor forecasting & $0 \%$ & $25 \%$ & $50 \%$ & $75 \%$ & $100 \%$ \\
\hline & $\begin{array}{l}\text { - Favorable attitude of Government } \\
\text { towards export quality products }\end{array}$ & $0 \%$ & $25 \%$ & $50 \%$ & $75 \%$ & $100 \%$ \\
\hline & $\begin{array}{l}\text { - Government Mismanagement and poor } \\
\text { follow up }\end{array}$ & $0 \%$ & $25 \%$ & $50 \%$ & $75 \%$ & $100 \%$ \\
\hline & - Low Remittance from abroad (UAE etc.) & $0 \%$ & $25 \%$ & $50 \%$ & $75 \%$ & $100 \%$ \\
\hline & $\begin{array}{l}\text { - Government Expenditure on Construc- } \\
\text { tion work }\end{array}$ & $0 \%$ & $25 \%$ & $50 \%$ & $75 \%$ & $100 \%$ \\
\hline & - Poor support/subsidy from government & $0 \%$ & $25 \%$ & $50 \%$ & $75 \%$ & $100 \%$ \\
\hline & - Stringent government regulations & $0 \%$ & $25 \%$ & $50 \%$ & $75 \%$ & $100 \%$ \\
\hline \multirow{7}{*}{$\begin{array}{l}\text { External } \\
\text { Factors }\end{array}$} & - Seasonal Effects & $0 \%$ & $25 \%$ & $50 \%$ & $75 \%$ & $100 \%$ \\
\hline & - International Influences & $0 \%$ & $25 \%$ & $50 \%$ & $75 \%$ & $100 \%$ \\
\hline & - Corruption at industry level & $0 \%$ & $25 \%$ & $50 \%$ & $75 \%$ & $100 \%$ \\
\hline & $\begin{array}{l}\text { - Difficulty in competing foreign ad- } \\
\text { vanced countries }\end{array}$ & $0 \%$ & $25 \%$ & $50 \%$ & $75 \%$ & $100 \%$ \\
\hline & - Poor Demand for products/services & $0 \%$ & $25 \%$ & $50 \%$ & $75 \%$ & $100 \%$ \\
\hline & - higher business cost and narrow margin & $0 \%$ & $25 \%$ & $50 \%$ & $75 \%$ & $100 \%$ \\
\hline & - Monopoly of Middlemen & $0 \%$ & $25 \%$ & $50 \%$ & $75 \%$ & $100 \%$ \\
\hline
\end{tabular}




\begin{tabular}{|c|c|c|c|c|c|c|}
\hline & - Political influence & $0 \%$ & $25 \%$ & $50 \%$ & $75 \%$ & $100 \%$ \\
\hline & - Non availability of Easy Credit & $0 \%$ & $25 \%$ & $50 \%$ & $75 \%$ & $100 \%$ \\
\hline & $\begin{array}{l}\text { - Extended and unscheduled power } \\
\text { failure }\end{array}$ & $0 \%$ & $25 \%$ & $50 \%$ & $75 \%$ & $100 \%$ \\
\hline \multicolumn{7}{|c|}{ Please furnish any suggestions you deem could improve the businesses } \\
\hline & Way out for overcoming some of the issues & & & & & \\
\hline $\begin{array}{c}\text { Internal } \\
\text { Factors }\end{array}$ & & & & & & \\
\hline \multicolumn{7}{|l|}{$\begin{array}{c}\text { Govern- } \\
\text { ment }\end{array}$} \\
\hline $\begin{array}{c}\text { External } \\
\text { Factors }\end{array}$ & & & & & & \\
\hline
\end{tabular}

